\title{
Shore-level size gradients and thermal refuge use in the predatory sea star Pisaster ochraceus: the role of environmental stressors
}

\author{
Cristián J. Monaco ${ }^{1,4, *}$, David S. Wethey ${ }^{1}$, Shadow Gulledge ${ }^{2}$, Brian Helmuth ${ }^{3}$ \\ ${ }^{1}$ Department of Biological Sciences, University of South Carolina, Columbia, SC 29208, USA \\ ${ }^{2}$ Environment and Sustainability Program, University of South Carolina, Columbia, SC 29208, USA \\ ${ }^{3}$ Marine Science Center, Northeastern University, Nahant, MA 01908, USA \\ ${ }^{4}$ Present address: Department of Zoology and Entomology, Rhodes University, Grahamstown 6140, South Africa
}

\begin{abstract}
The body size of a mobile intertidal invertebrate can determine its access to different microhabitats, and thus alter its exposure to environmental stressors. We surveyed a rocky intertidal keystone predator, the sea star Pisaster ochraceus, and characterized size-dependent distribution, defined by individuals' shore level and refuge use. At 2 field sites (in California and Oregon, USA) we examined temporal and geographical variability in habitat selection. We evaluated the hypothesis that environmental drivers measured on-site and body temperatures measured using biomimetic sensors (i.e. 'robo-sea stars'), explained the observed distribution patterns, including shore-level size gradients, with larger animals lower on the shore. We tested the effect of size on animals' thermo- and desiccation-tolerance. Using robo-sea star data, thermal performance curves and critical temperatures of different size classes, we investigated potential physiological and survival consequences of microhabitat use (shaded vs. sun-exposed). Pisaster is mostly found in thermal refugia during low tide even when the risk of thermal stress in sun-exposed areas is low, suggesting a risk-avoidance strategy. In sheltered microhabitats, Pisaster exhibited shore-level size gradients; in sun-exposed microhabitats, this pattern disappeared. The proportion of individuals found in shaded microhabitats increased with air temperature, solar radiation, and body temperature. Size-dependent sensitivity to stressful temperatures and wind speed did not explain the observed distribution patterns, suggesting that in the field, size constraints prevent larger animals from occupying refuges that small individuals can use. Our data reveal that, despite generally mild conditions, Pisaster risk-avoidance strategy buffers against rare but potentially highly stressful events.
\end{abstract}

KEY WORDS: Ecology · Physiology · Rocky intertidal · Environmental stress · Climate change · Temperature $\cdot$ Desiccation $\cdot$ Solar radiation $\cdot$ Body size $\cdot$ Behavior

\section{INTRODUCTION}

A variety of mobile intertidal species exhibit shorelevel gradients in body size. Several hypotheses have been put forward to explain these patterns, each of which yield different predictions of whether smaller individuals should be more common higher on the shore, or lower on the shore. Vermeij (1972) found that smaller individuals of shelled gastropod species common to the low intertidal zone were typically found only at higher shore elevations, presumably because predation and competition pressures on those vulnerable individuals decrease at those heights (see also Paine 1969). Bertness (1977) provided evidence that energy maximization played a role for the predatory snails Nucella spp. that chose 
shore heights based on their preference for consuming specific prey sizes. In contrast, shore-level size gradients in some grazing gastropods appear to be related to environmental stress gradients. Frank (1965) argued that differential sensitivity to temperature and desiccation between size classes leads to larger limpets Lottia digitalis occurring higher on the shore. In contrast, studying the topshell snail $O x y$ stele variegata, McQuaid (1982) noted that higher desiccation experienced by smaller individuals due to their increased surface area to volume ratio prevents these individuals from occupying higher shore levels, as larger ones do. Raffaelli \& Hughes (1978) showed that the availability and size of refuges can drive size gradients across the intertidal zone in Littorina spp. snails.

Here, we examined microhabitat use by a keystone predator, the rocky intertidal sea star Pisaster ochraceus (Brandt, 1835) (hereafter, Pisaster) in order to distinguish among alternative mechanisms responsible for shore-level size gradients. Because of its role as a keystone predator, Pisaster has been the subject of extensive ecological and physiological research (e.g. Paine 1966, 1974, Robles et al. 1995, Sanford 1999). Pisaster inhabits wave-exposed rocky shores on the Pacific coast of North America, where cyclic tides, recurrent upwelling, and topographic complexity set the scene for an extremely heterogeneous thermal environment (Helmuth \& Hofmann 2001, Broitman et al. 2009, Jackson 2010).

The impact of Pisaster on populations of its main prey, the mussel Mytilus californianus, is indirectly mediated by body temperatures experienced during periods of low and high tide (Sanford 1999, Pincebourde et al. 2008). Pisaster forages during submersion at high tide, and then either retreats to a shelter prior to emersion at low tide or else remains in place, continuing to ingest its prey (Robles et al. 1995). As a result, depending on where a sea star finds itself when the tide recedes, it can either be exposed to potentially stressful thermal and desiccation stresses, or protected in crevices, tide pools, or under algae (Burnaford \& Vasquez 2008, Fly et al. 2012). Being exposed to waves while foraging at high tide may also imply having to cope with the impact of wave-generated forces (Denny et al. 1985). Previous studies have observed shore-level size gradients in Pisaster, with larger individuals found lower on the shore (Feder 1956, Fly et al. 2012). Unlike other smaller species, however, the size range of Pisaster ( 0.1 to $20 \mathrm{~cm}$ arm length) is quite large and in some cases similar to that of the physical habitat. Thus, a microhabitat that may serve as an effective refuge for a small animal may be inaccessible to a larger individual (Raffaelli \& Hughes 1978, Gedan et al. 2011). Additionally, these highly mobile animals can travel several meters per day during high tide (Robles et al. 1995), and individuals can thus be found at different elevations (from shallow subtidal to mid-high intertidal; Pincebourde et al. 2008, Garza \& Robles 2010), implying exposure to different degrees of physical stress (Marshall et al. 2013).

Here, we approached the issue through both fieldand laboratory-based observations. First, using data from repeated field surveys (2010-2012) conducted at 2 sites $770 \mathrm{~km}$ apart, we characterized Pisaster refuge use and shore level to assess how consistent patterns were through space and time. Second, we tested whether the variability in these patterns could be explained by changes in environmental drivers (air temperature, seawater temperature, solar radiation, wind speed, and wave action) or by their cumulative impacts on body temperature. Third, we conducted laboratory experiments to determine whether differences in thermo- and desiccation-tolerance between size classes can explain the observed pattern. According to the oxygen-limitation hypothesis (Pörtner 2002, 2006), and supporting evidence (Peck et al. 2009, 2013), we hypothesized that smaller individuals can withstand higher temperatures than larger ones because they have a proportionately larger respiratory surface area relative to volume of tissue.

One might also expect that the larger surface area to volume ratio exhibited by small animals would increase water loss during exposure to wind, with a consequent reduction in performance, relative to larger individuals (Stevenson 1985, Allen et al. 2012). However, previous accounts for Pisaster (Feder 1956, Landenberger 1969) have suggested that this may not be the case. Feder (1956) found that smaller Pisaster are not more vulnerable to losing water through evaporation, nor of showing earlier signs of physical distress (i.e. body wall flattening, failure of tube feet to attach) (Landenberger 1969). To test the hypothesis that size does not have a strong effect on desiccation tolerance, we exposed individuals to a constant wind speed that paralleled average in situ measurements made during a representative lowtide period, and measured performance during simulated high tides.

The relevant hypotheses depend on small-scale differences in temperature, but there are almost no records from the exact spots occupied or avoided by Pisaster over the course of the tides. We met this need with biomimetic temperature loggers ('robo-sea 
stars'). Using these approaches, we aimed to determine the mechanisms driving patterns of distribution in Pisaster, and their role in defining zonation patterns. As previously recognized, Pisaster upper shore limits at low tide are set by high air temperatures (Robles et al. 1995), a process that is likely mediated by sublethal effects of temperature on physiological performance (Pincebourde et al. 2008, Robles 2013). Because vertical movement may imply increased energy expenditure to cope with physiological thermal stress (either acute or chronic, sensu Pincebourde et al. 2008), we expected Pisaster to behaviorally compensate for these costs by preferentially seeking protected microhabitats.

\section{MATERIALS AND METHODS}

\section{Study sites}

We conducted field surveys at 2 study sites: Strawberry Hill $\left(44^{\circ} 14^{\prime} 59.4^{\prime \prime} \mathrm{N}, 1^{\circ} 4^{\circ} 06^{\prime} 54.7^{\prime \prime} \mathrm{W}\right.$, Oregon, USA), and Bodega Marine Reserve (38 $18^{\circ}$ $07.7^{\prime \prime} \mathrm{N}, 123^{\circ} 04^{\prime} 27.0^{\prime \prime} \mathrm{W}$, California, USA), separated by $\sim 770 \mathrm{~km}$ of coastline. We limited our analysis to wave-exposed rocky shores, where this keystone predator plays a more critical ecological role (Paine 1966, 1974, Menge et al. 1994, Power et al. 1996). Both sites had dense mid-intertidal mussel beds and were topographically complex, providing alternative microhabitats for sea stars to occupy, including crevices, tide pools, kelps, and open spaces. At the time of the surveys, wasting disease (Hewson et al. 2014) had not yet affected populations, and abundances at all sites were high.

\section{Intertidal distribution surveys}

To describe Pisaster microhabitat use (shore level and refuge use) at each study site and survey date, we sampled every individual encountered along 5 belt-transects ( $2 \mathrm{~m}$ wide), placed non-randomly $1 \mathrm{~m}$ apart and perpendicular to the coastline. Transects extended from the height of the highest Pisaster individual found to the low water level limit set by the spring tide. We conducted all surveys during the time of negative tide heights, as predicted by NOAA (stations 9435380 and 9415020 for Strawberry Hill and Bodega, respectively). For each sea star, we recorded body size and microhabitat use. We determined size from wet weight measurements taken with a portable balance (Ohaus SP202, 200 g) or a spring scale (Pesola, $1000 \mathrm{~g}$ ), depending on the animal's size. We characterized the microhabitat by (1) shore level (cm above MLLW), measured using a surveying laser level (Topcon), and (2) refuge use, which was designated as either heat-protected (i.e. crevice, tide pool, under kelp) or sun-exposed (i.e. flat, receiving solar radiation). We used regression analysis to determine shore-level size gradients from the data collected during each survey (see 'Statistical analyses' below).

To evaluate temporal dynamics in sea star distribution patterns, we surveyed Strawberry Hill and Bodega on multiple spring tide periods during the summer of 2012 (Strawberry Hill: 24 May, 22 June, 20 July, and 3 August; Bodega: 22 May, 8 June, 20 June, 19 July, and 1 August). Bodega was additionally surveyed during the summers of $2010(2,16$, and 28 June) and 2011 (19 May, 4 June, 15 June, 1 July, and 14 July); thus inter-annual comparisons could be performed. To examine spatial variability, we compared data between sites collected in the same year (2012).

\section{Population density and foraging activity}

The intertidal distribution surveys were additionally used to quantify population densities at both sites and to describe foraging activity. During 2011 and 2012 at Bodega, and 2012 at Strawberry Hill, we recorded (1) whether sea stars were found consuming mussels (i.e. digesting with stomach everted), and (2) distance to closest mussel bed edge.

\section{Influence of environmental drivers}

We examined the effect of changes in relevant environmental variables on the intertidal distribution patterns (shore-level size gradients and refuge use) exhibited by Pisaster. We tested the effects of seawater temperature (Sanford 1999), air temperature (Pincebourde et al. 2008), wind speed (Landenberger 1969), wave action (Sanford 2002), and solar radiation (Burnaford \& Vasquez 2008), since all have been shown to affect sea star physiology, body temperature, and/or behavior (Szathmary et al. 2009). We used data collected hourly by a weather station (200 $\mathrm{m}$ from the survey area) and associated wave height radar and seawater temperature sensors maintained by the Bodega Ocean Observing Node (www.bml.ucdavis.edu/boon/). Because onsite data were not available for Strawberry Hill, we 
conducted this analysis only for Bodega. We manipulated the data series as follows. First, we used aerial data corresponding to $1 \mathrm{~d}$ prior to each population survey, since aerial conditions would have had their impact during the previous day's aerial exposure (Szathmary et al. 2009). We only used seawater temperature and wave height data recorded during high tide periods ( $>1 \mathrm{~m}$ above MLLW), and only used air temperature, wind speed, and solar radiation data recorded during low tide periods $(\leq 1 \mathrm{~m}$ above MLLW). For each driver, we determined the daily maxima, which were regressed against our field observations of Pisaster distribution.

The analysis addressed 2 main elements of Pisaster distribution that could potentially depend on environmental variability. First, we looked for relationships between shore-level size gradients and the 5 environmental drivers; second, we tested whether these drivers explained changes in refuge use.

\section{Size-dependent aerial thermotolerance: laboratory experiment}

To evaluate the effect of Pisaster body size on its aerial thermotolerance, we conducted experiments to estimate the lethal temperature $\left(\mathrm{LT}_{50}\right.$, temperature at which $50 \%$ of the individuals die) of 2 size classes, small (25-75 g, $\mathrm{N}=34$ ) and large (250-400 g, $\mathrm{N}=33$ ). We ran these experiments in July 2011, at the Bodega Marine Laboratory (BML, University of California Davis).

We collected the Pisaster at Bodega, and held them in tanks with running seawater and food (Mytilus californianus) provided ad libitum. We withdrew their food supply $24 \mathrm{~h}$ before the start of the experiment to standardize physiological condition. Before beginning the experimental treatments, we recorded each individual's wet weight. We placed specimens (up to 2, avoiding contact between them) on gray acrylic platforms positioned $25 \mathrm{~cm}$ above the bottom of $75 \mathrm{l}$ tanks. Below the platform, we provided a constant stream of seawater to maintain high levels of ambient humidity. A heat lamp $(150 \mathrm{~W})$ was used to adjust animals' temperature during each trial. Using an infrared thermometer (Model OS36, Omega), we measured the surface temperature of each individual's central disc every $15 \mathrm{~min}$. We ran each trial for $6 \mathrm{~h}$. During the first $3 \mathrm{~h}$, we gradually increased body temperature from ambient seawater temperature $\left(\sim 12^{\circ} \mathrm{C}\right)$ to the treatment temperatures $\left(24-40^{\circ} \mathrm{C}\right.$, in $2^{\circ} \mathrm{C}$ increments). During the last $3 \mathrm{~h}$, we maintained the treatment temperature at constant levels. At the end of $6 \mathrm{~h}$, animals were returned to running seawater at $12^{\circ} \mathrm{C}$. Survival was assessed after $24 \mathrm{~h}$ in running seawater by probing the tube feet and evaluating their response.

\section{Size-dependent desiccation tolerance: laboratory experiment}

To evaluate the effect of Pisaster body size on its tolerance to desiccation, we quantified the performance of individuals ranging in size (7.1-780.1 $\mathrm{g}, \mathrm{N}=$ 26) after consecutive, $6 \mathrm{~h}$ daily exposures to wind of 3.5-4.0 $\mathrm{m} \mathrm{s}^{-1}$. We ran these experiments during July 2011 at BML.

We collected and prepared the animals as described for the thermotolerance experiment. We determined each individual's performance on 4 consecutive days: (1) Day 0, $1 \mathrm{~d}$ prior to beginning the experiment, which defined a baseline; (2) Day 1, after a first exposure to the wind treatment; (3) Day 2, after a second wind exposure; and (4) Day 3, after a final, third wind exposure. We assessed performance based on righting response time $(R T$; seconds), the length of time required to move to an upright position. We calculated an activity coefficient: $A C=1000 / R T$ (Lawrence \& Cowell 1996). The mean $A C$ from Days 1, 2, and 3 was subtracted from the Day 0 reference $A C$ of each individual, thus obtaining a relative measure of the effect of desiccation. These data were modified by adding a positive offset value in order to have only positive numbers, which were then analyzed in relation to body size.

\section{Robo-sea star temperature records}

To assess the temperatures individuals would experience in different microhabitats (potential body temperature), we used biomimetic temperature loggers (iButton DS1922, $0.0625^{\circ} \mathrm{C}$ resolution) embedded within a solid disc of foam (Aquazone single cell, Reilly Foam) to resemble the thermal properties of an average size Pisaster, $200 \mathrm{~g}$ (Szathmary et al. 2009). We deployed the sensors (robo-sea stars) at Strawberry Hill and Bodega during the summer of 2012, and continuously recorded (15 min sampling interval) Pisaster body temperature in sun-exposed (high, mid-, and low intertidal heights) and heat-protected microhabitats (crevices and tide pools). 


\section{Physiological performance and survival consequences of body temperature}

We used the robo-sea star temperature data to evaluate the physiological implications, as well as potential mortality effects, of selecting each microhabitat type. Physiological consequences were quantified based on a Pisaster thermal performance curve (Monaco et al. 2014), to calculate the temperature dependence of respiration rates (a proxy for physiological performance). Mortality was estimated from cumulative survival curves for each microhabitat type, size class, and site. The cumulative probability of survival was calculated daily using the exponential function, based on estimates from the $\mathrm{LT}_{50}$ logistic models.

\section{Statistical analyses}

All statistical analyses were conducted using $\mathrm{R}$ 3.0.1 (R Core Team 2013). To determine the effect of body size on individuals' intertidal height (i.e. shorelevel size gradients) we ran regression analyses using data collected during each survey (e.g. Bertness 1977, Hobday 1995). To test whether microhabitat use would change the nature of these relationships, microhabitat type was included in the models as a categorical variable. Due to lack of normality in the data, we used generalized linear models (GLMs) and generalized linear mixed effects models when appropriate, assuming gamma (modified with 'identity' link function) error distributions, which yielded the lowest dispersion (determined using the 'gamma. dispersion' function from the MASS package in R). Because the sample sizes were unbalanced between surveys, we computed significance of model parameters via likelihood ratio tests (LRTs) using Type II sums of squares. We checked for homogeneity of variances by visual inspections of diagnostic plots of residuals vs. fitted data (R package car; http://CRAN. R-project.org/package $=$ car) .

To determine whether shore-level size gradients and refuge use patterns varied among survey dates (i.e. temporal variability) at each site and year, we ran ANCOVAs with date as the main factor. We did not combine data from different years because population densities varied annually. To examine whether shore-level size gradients and microhabitat use patterns varied between sites, we ran ANCOVAs with site as the main factor, using data from 2012 because surveys at Strawberry Hill were only conducted that year.
To examine the relationships between shore-level size gradients and daily maxima of the 5 environmental drivers, we ran multiple regression analyses, where the slope of the regression lines between Pisaster intertidal height and wet weight (see Table 1) was the response variable (weighted by the inverse of their associated SE), and all 5 drivers were treated as independent variables. We tested whether these drivers explained changes in the proportion of individuals found in sun-exposed microhabitats during low-tide surveys (i.e. refuge use) using multiple logistic regressions, treating exposure (heat-protected/sun-exposed) as response and the 5 environmental drivers as independent variables. Air temperature and solar radiation were collinear (variance inflation factor $>10$; Quinn \& Keough 2002). To avoid collinearity problems, we ran the regressions twice, once including air temperature and excluding solar radiation, and vice versa.

We compared Pisaster population density data and distance to mussel beds between sites using Wilcoxon rank-sum tests. To evaluate the effect of site on the proportion of $M$. californianus found in the diet of Pisaster, we used GLM with binomial error distributions and computed the significance of model parameters via LRT.

Pisaster thermotolerance survival data for each size class were fitted using logistic regression models estimated by GLMs with binomial error distributions. We determined $\mathrm{LT}_{50} \mathrm{~s}$ from these models, and compared them using a 1-tailed $z$-score test (Quinn \& Keough 2002).

The relationship between body size and Pisaster relative performance after desiccation (wind) was described by a 2-parameter asymptotic exponential model. The asymptote of the fitted curve was the size at which performance was least affected by desiccation. Individuals performing below 2 SEs of the asymptote were regarded as significantly affected by desiccation.

To compare the temperature time series obtained from the robo-sea stars at different tidal elevations and microhabitat types, we calculated mean absolute errors (MAEs) and ran paired $t$-tests using daily maximum values. For each site, we used the high intertidal sun-exposed robo-sea star (expected to have the highest temperatures) as the reference time series against which all other robo-sea stars were compared. Physiological implications of selecting each microhabitat were quantified using a thermal performance curve for Pisaster (Monaco et al. 2014). Using the thermal performance breadth parameter $\left(17.2-23.8^{\circ} \mathrm{C}\right.$, i.e. the temperature range where per- 
formance is $\geq 69 \%$ of maximum; Sharpe $\&$ DeMichele 1977), we calculated the percentage of time Pisaster would have spent below, above, and within that range at each microhabitat. Potential mortality effects of body temperature were evaluated based on cumulative survival curves for each microhabitat, size class, and site. We calculated survival using the logistic functions modeled from our size-dependent thermotolerance experiments, and the robo-sea stars' temperature records.

\section{RESULTS}

\section{Pisaster intertidal distribution}

Year-to-year changes in Pisaster demographics (density and size-frequency distribution) at Bodega were large (mean density 2011: $0.52 \mathrm{~m}^{-2}$, 2012: $0.01 \mathrm{~m}^{-2}$ ). Therefore, we grouped the data by year and site, and examined temporal dynamics occurring among survey dates. The relationships between intertidal height, refuge use, and body size in Pisaster were highly variable (Table 1 and see Figs. S1 \& S2 in the Supplement, available at www.int-res.com/articles/suppl/ m539p191_supp.pdf), although some generalizations could be made. We provide specific findings below.

Most individuals were found protected from the sun either in crevices, tide pools, or under algae (Table 1). We found extensive evidence for shore-level size gradients. At Bodega, in 8 of 12 surveys from 2010 to 2012, there was a negative relationship between body size and shore height in heat-protected microhabitats (Table 1). In sunexposed microhabitats, we found no relationship between body size and shore height in 11 of 12 surveys (Table 1). In the remaining case in sun-exposed microhabitats, there was a positive relationship. At Strawberry Hill, the patterns were less clear. In 2 of 4 cases in heat-protected microhabitats, significant relationships were evident between body size and shore level, but 1 relationship was positive and the other negative. In no case was there a relationship in sun-exposed microhabitats at Strawberry Hill (Table 1).
Table 1. Pisaster ochraceus size-dependent distribution. Regression lines were fitted using a generalized linear model (gamma error distribution). $\mathrm{NaN}$ indicates that the parameter could not be calculated because no ividual was found in that location. Significance of model parameters were computed via likelihood ratio tests (LRTs) using Type II sums of squares. HP: heat-protected, SE: sun-exposed ${ }_{i}{ }^{*} \mathrm{p}<0.05,{ }^{* *} \mathrm{p}<0.01$; date: $\mathrm{mo} / \mathrm{d} / \mathrm{yr}$

\begin{tabular}{|c|c|c|c|c|c|}
\hline $\begin{array}{l}\text { Site/ } \\
\text { survey date }\end{array}$ & $\begin{array}{l}\text { Micro- } \\
\text { habitat }\end{array}$ & $\mathrm{N}$ & $\begin{array}{c}\% \text { at micro- } \\
\text { habitat }\end{array}$ & $\begin{array}{c}\text { Slope } \\
\text { mean } \pm \text { SE }\end{array}$ & $\mathrm{p}$ \\
\hline \multicolumn{6}{|c|}{ Strawberry Hill, OR } \\
\hline \multirow[t]{2}{*}{$05 / 24 / 2012$} & $\mathrm{HP}$ & 49 & 62.82 & $-0.147 \pm 0.021$ & $0.008^{* *}$ \\
\hline & $\mathrm{SE}$ & 29 & 37.18 & $0.089 \pm 0.059$ & 0.129 \\
\hline \multirow[t]{2}{*}{ 06/22/2012 } & $\mathrm{HP}$ & 37 & 71.15 & $0.091 \pm 0.061$ & 0.205 \\
\hline & $\mathrm{SE}$ & 15 & 28.85 & $0.019 \pm 0.070$ & 0.789 \\
\hline \multirow[t]{2}{*}{ 07/20/2012 } & $\mathrm{HP}$ & 49 & 63.64 & $0.126 \pm 0.052$ & $0.042^{*}$ \\
\hline & $\mathrm{SE}$ & 28 & 36.36 & $-0.022 \pm 0.044$ & 0.659 \\
\hline \multirow[t]{2}{*}{ 08/03/2012 } & $\mathrm{HP}$ & 66 & 92.96 & $0.027 \pm 0.037$ & 0.518 \\
\hline & $\mathrm{SE}$ & 5 & 7.04 & $0.181 \pm 0.179$ & 0.246 \\
\hline \multicolumn{6}{|c|}{ Bodega Marine Reserve, CA } \\
\hline \multirow[t]{2}{*}{ 06/02/2010 } & HP & 198 & 71.22 & $-0.021 \pm 0.015$ & 0.156 \\
\hline & $\mathrm{SE}$ & 80 & 28.78 & $-0.003 \pm 0.025$ & 0.908 \\
\hline \multirow[t]{2}{*}{ 06/16/2010 } & $\mathrm{HP}$ & 234 & 84.78 & $-0.054 \pm 0.012$ & $0.000^{* *}$ \\
\hline & $\mathrm{SE}$ & 42 & 15.22 & $-0.015 \pm 0.023$ & 0.488 \\
\hline \multirow[t]{2}{*}{ 06/28/2010 } & $\mathrm{HP}$ & 267 & 88.41 & $-0.023 \pm 0.009$ & $0.010^{* *}$ \\
\hline & $\mathrm{SE}$ & 35 & 11.59 & $-0.004 \pm 0.016$ & 0.791 \\
\hline \multirow[t]{2}{*}{ 05/19/2011 } & $\mathrm{HP}$ & 107 & 74.31 & $-0.058 \pm 0.022$ & $0.007^{* *}$ \\
\hline & $\mathrm{SE}$ & 37 & 25.69 & $0.015 \pm 0.039$ & 0.713 \\
\hline \multirow[t]{2}{*}{ 06/04/2011 } & $\mathrm{HP}$ & 110 & 77.46 & $-0.004 \pm 0.023$ & 0.871 \\
\hline & $\mathrm{SE}$ & 32 & 22.54 & $0.072 \pm 0.024$ & $0.004^{* *}$ \\
\hline \multirow[t]{2}{*}{ 06/15/2011 } & $\mathrm{HP}$ & 153 & 82.26 & $-0.046 \pm 0.015$ & $0.003^{* *}$ \\
\hline & $\mathrm{SE}$ & 33 & 17.74 & $0.052 \pm 0.050$ & 0.314 \\
\hline \multirow[t]{2}{*}{ 07/01/2011 } & $\mathrm{HP}$ & 160 & 87.91 & $-0.062 \pm 0.017$ & $0.000^{* *}$ \\
\hline & $\mathrm{SE}$ & 22 & 12.09 & $-0.046 \pm 0.123$ & 0.713 \\
\hline \multirow[t]{2}{*}{ 07/14/2011 } & $\mathrm{HP}$ & 139 & 83.23 & $-0.055 \pm 0.017$ & $0.001^{* *}$ \\
\hline & $\mathrm{SE}$ & 28 & 16.77 & $0.015 \pm 0.028$ & 0.595 \\
\hline \multirow[t]{2}{*}{ 05/22/2012 } & $\mathrm{HP}$ & 37 & 100.00 & $-0.027 \pm 0.010$ & $0.010^{*}$ \\
\hline & $\mathrm{SE}$ & 0 & 0 & $\mathrm{NaN}$ & $\mathrm{NaN}$ \\
\hline \multirow[t]{2}{*}{ 06/08/2012 } & $\mathrm{HP}$ & 19 & 100.00 & $-0.003 \pm 0.012$ & 0.804 \\
\hline & $\mathrm{SE}$ & 0 & 0 & $\mathrm{NaN}$ & $\mathrm{NaN}$ \\
\hline \multirow[t]{2}{*}{ 06/20/2012 } & $\mathrm{HP}$ & 21 & 84.00 & $-0.023 \pm 0.012$ & $0.034^{*}$ \\
\hline & $\mathrm{SE}$ & 4 & 16.00 & $0.040 \pm 0.025$ & 0.248 \\
\hline \multirow[t]{2}{*}{ 07/19/2012 } & $\mathrm{HP}$ & 20 & 90.91 & $-0.014 \pm 0.013$ & 0.304 \\
\hline & $\mathrm{SE}$ & 2 & 9.09 & $\mathrm{NaN}$ & $\mathrm{NaN}$ \\
\hline
\end{tabular}

\section{Population density and foraging activity}

At Strawberry Hill, individual sea stars were found farther from beds of Mytilus californianus mussels, their preferred prey, compared to at Bodega (mean \pm SD: $256.7 \pm 207.8 \mathrm{~cm}$ vs. $77.8 \pm$ $63.3 \mathrm{~cm}$, respectively; Wilcoxon test, $W=5746.5, \mathrm{p}<$ 0.01 ). This is possibly a result of the higher population density at Strawberry Hill (mean \pm SD: $3.95 \pm$ 0.86 ) vs. Bodega (mean $\pm \mathrm{SD}$ : $0.31 \pm 0.27$; Wilcoxon test, $W=0, \mathrm{p}<0.05$ ), and consequently a stronger predation pressure, which would push mussel bed boundaries higher on the shore. At Bodega, where 


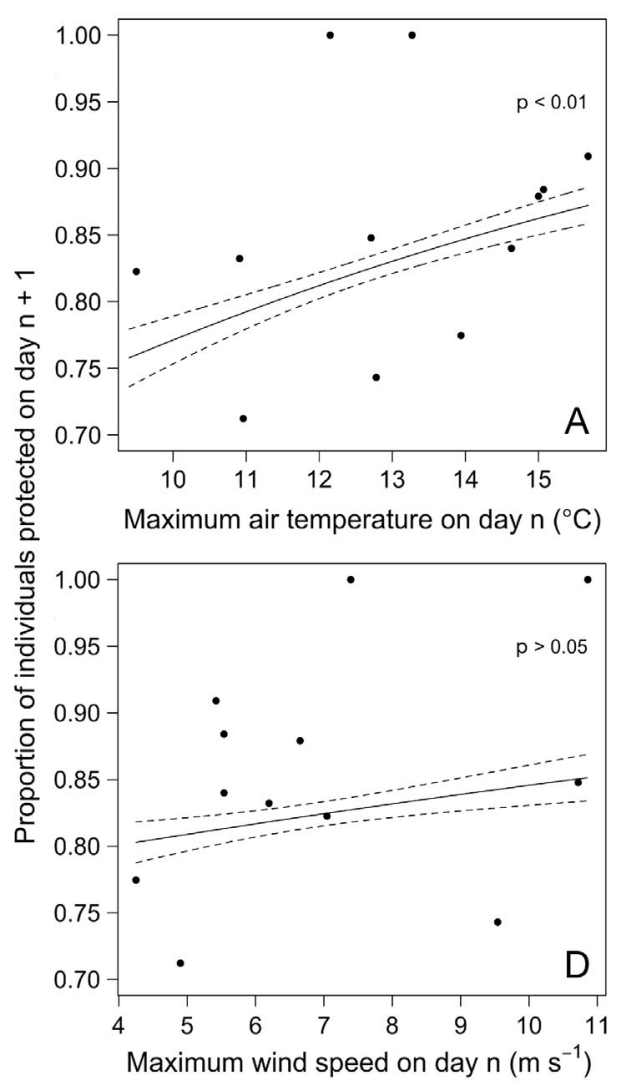

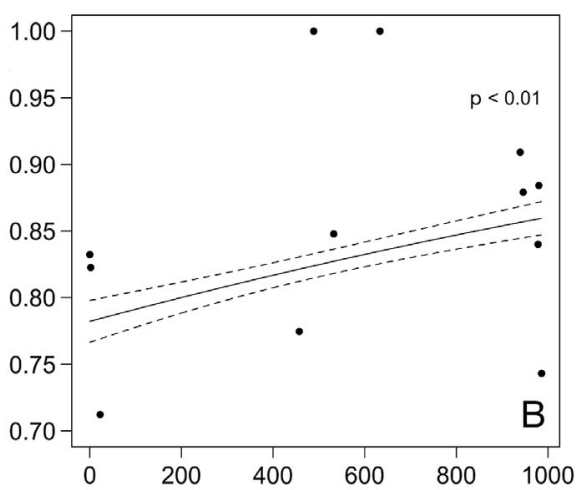

Maximum solar radiation on day $\mathrm{n}\left(\mathrm{W} \mathrm{m}^{-2} \mathrm{~s}^{-1}\right)$

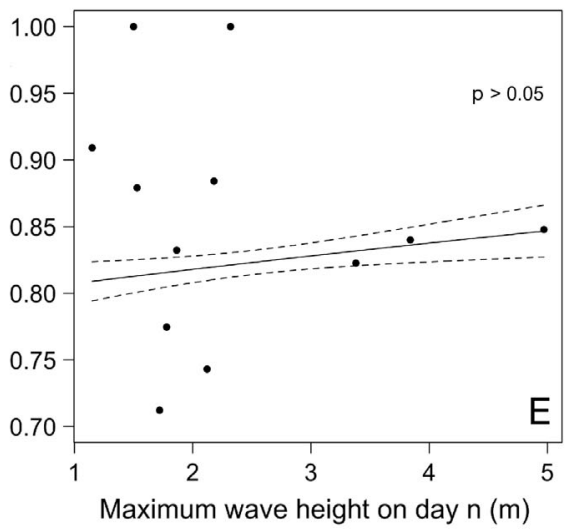

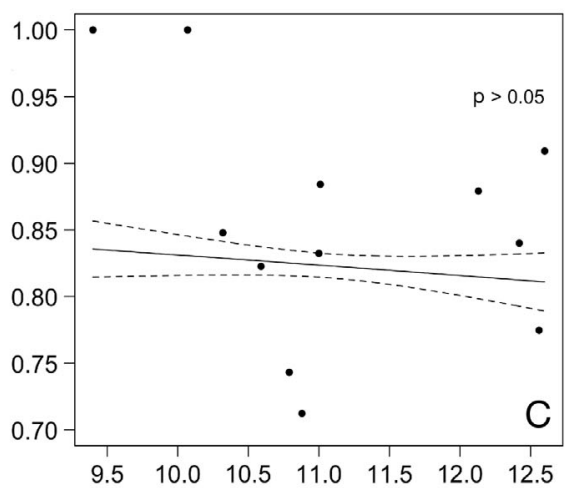

Maximum seawater temperature on day $n\left({ }^{\circ} \mathrm{C}\right)$

Fig. 1. Proportion of Pisaster ochraceus individuals found in heat-protected thermal refugia on Day $n+1$ vs. relevant environmental variables on Day n: (A) air temperature, (B) solar radiation, (C) sea water temperature, (D) wind speed, and (E) wave height. Proportions were calculated for each survey conducted at Bodega Marine Reserve, CA. Raw data for environmental variables was retrieved from the Bodega Ocean Observing Node sensor station. For this figure, we used the daily maximum values. The lines represent logistic regression fits $\pm 1 \mathrm{SE}$
Pisaster were closer to $M$. californianus than at Strawberry Hill, sea stars were found eating proportionally more mussels (mean \pm SD: $0.83 \pm 0.29,0.31$ \pm 0.19 , respectively; LRT, $\chi^{2}=58.6, \mathrm{df}=1, \mathrm{p}<0.01$ ) than small, less profitable prey (e.g. barnacles). These observations may account for the higher proportion of sun-exposed individuals observed at Strawberry Hill vs. Bodega (see above).

\section{Role of environmental drivers and how they translate to the organism}

Contrary to expectations, we observed no relationship between any of the 5 environmental variables (air temperature, solar radiation, seawater temperature, wave height, wind speed) and the shore-level size gradients of Pisaster at Bodega. This was true for both heat-protected and sunexposed individuals (Table S1 in the Supplement). Although the proportion of individuals found in sunexposed microhabitats was consistently low (Table 1), the proportion of sun-exposed animals was negatively correlated with both air temperature (Fig. 1A; LRT, $\chi^{2}=22.5, \mathrm{df}=1, \mathrm{p}<0.01$ ) and solar radiation (Fig. 1B; LRT, $\chi^{2}=12.8$, df $=1, \mathrm{p}<0.01$ ) during the day prior to our field population surveys. While the model that included solar radiation as an independent variable did not detect an effect of seawater temperature on Pisaster refuge use (Fig. 1C; LRT, $\chi^{2}=1.9$, df $\left.=1, \mathrm{p}>0.05\right)$, the model that considered air temperature revealed a positive influence of seawater temperature (LRT, $\chi^{2}=4.3, \mathrm{df}=1$, $\mathrm{p}<0.05)$. We detected no relationship between proportion of Pisaster in refuge and wave height (Fig. 1E; LRT, $\chi^{2}=0.48, \mathrm{df}=1, \mathrm{p}>0.05$ ), or wind speed (Fig. 1D; LRT, $\chi^{2}=0.07$, df $=1, p>0.05$ ) recorded during summer months.

Because ectotherm body temperatures are driven by multiple environmental variables (Helmuth 2002, Broitman et al. 2009, Szathmary et al. 2009), we examined the influence of maximum temperatures recorded by robo-sea stars $1 \mathrm{~d}$ prior to the surveys. Contrary to expectation, there were no significant relationships between shore-level size gradients and robo-sea star temperatures in low, mid-, and high intertidal heights as measured by the regression slopes in Table 1 (LRT; p > 0.05 in all cases). However, there was a positive association between temperatures recorded by robo-sea stars deployed at low (Fig. 2A; LRT, $\chi^{2}=10.2, \mathrm{df}=1, \mathrm{p}<0.01$ ) and mid(Fig. 2B; LRT, $\chi^{2}=17.2$, df $=1, \mathrm{p}<0.01$ ) intertidal 
heights and Pisaster refuge use on the next day. There was no association between high intertidal robo-sea star temperature and the proportion of individuals in heat-protected microhabitats (Fig. 2C; LRT, $\chi^{2}=0.2, \mathrm{df}=1, \mathrm{p}=0.35$ ). Daily potential body temperature maxima as measured by robo-sea stars were higher than daily air temperature maxima (cf. Figs. $1 \mathrm{~A} \& 2 ; \mathrm{MAE}=3.18^{\circ} \mathrm{C}$ ).

\section{Size-dependent tolerance to thermal and desiccation stress}

Contrary to expectation, large Pisaster individuals showed a significantly higher median lethal temperature $\left(\mathrm{LT}_{50}\right)$ than small animals (Fig. 3; mean $\pm \mathrm{SE}$; large $=33.3 \pm 0.9^{\circ} \mathrm{C} ;$ small $=31.6 \pm 0.5^{\circ} \mathrm{C} ; z=-1.76$; $\mathrm{p}=0.04)$.

Consistent with expectation, the effect of wind (and hence desiccation) on the activity coefficient of Pisaster depended on individual size (Fig. 4). According to the 2-parameter asymptotic exponential model, all animals smaller than $83.7 \mathrm{~g}$ (7 individuals) had significantly reduced performance with respect to the asymptote after exposure to continuous wind during simulated low tide periods. Of 19 individuals larger than $83.7 \mathrm{~g}$ treated, only $3(15.7 \%)$ reduced their activity coefficient with respect to the model's asymptote.

\section{Robo-sea star temperature records}

Pisaster body temperatures, as determined using robo-sea stars, varied among microhabitats and sites during low tides. We focused on daily temperature maxima due to their importance for individual survival and fitness. At both sites, the high intertidal sun-exposed robo-sea star temperatures were consistently higher than other microhabitats (mean differences; Bodega $=9.05^{\circ} \mathrm{C}$; Strawberry Hill $=2.07^{\circ} \mathrm{C}$; paired $t$-tests, $\mathrm{p}<0.01$ in all cases) and more variable (mean variance ratios; Bodega $=10.13$; Strawberry Hill $=4.58 ; F$-tests, $\mathrm{p}<0.01$ in all cases, except for the low intertidal and tide pool robo-sea stars at Strawberry Hilli Fig. 5). MAE and variance ratios between sun-exposed and heat-protected microhabitats were greater at Bodega than Strawberry Hill (Fig. 5). At Strawberry Hill, the coolest microhabitats were crevices; at Bodega, low intertidal, crevices, and tide pools were coolest (Fig. 5). As a caveat, the relatively high temperatures recorded by low intertidal and tide pool robo-sea stars at Strawberry Hill are likely
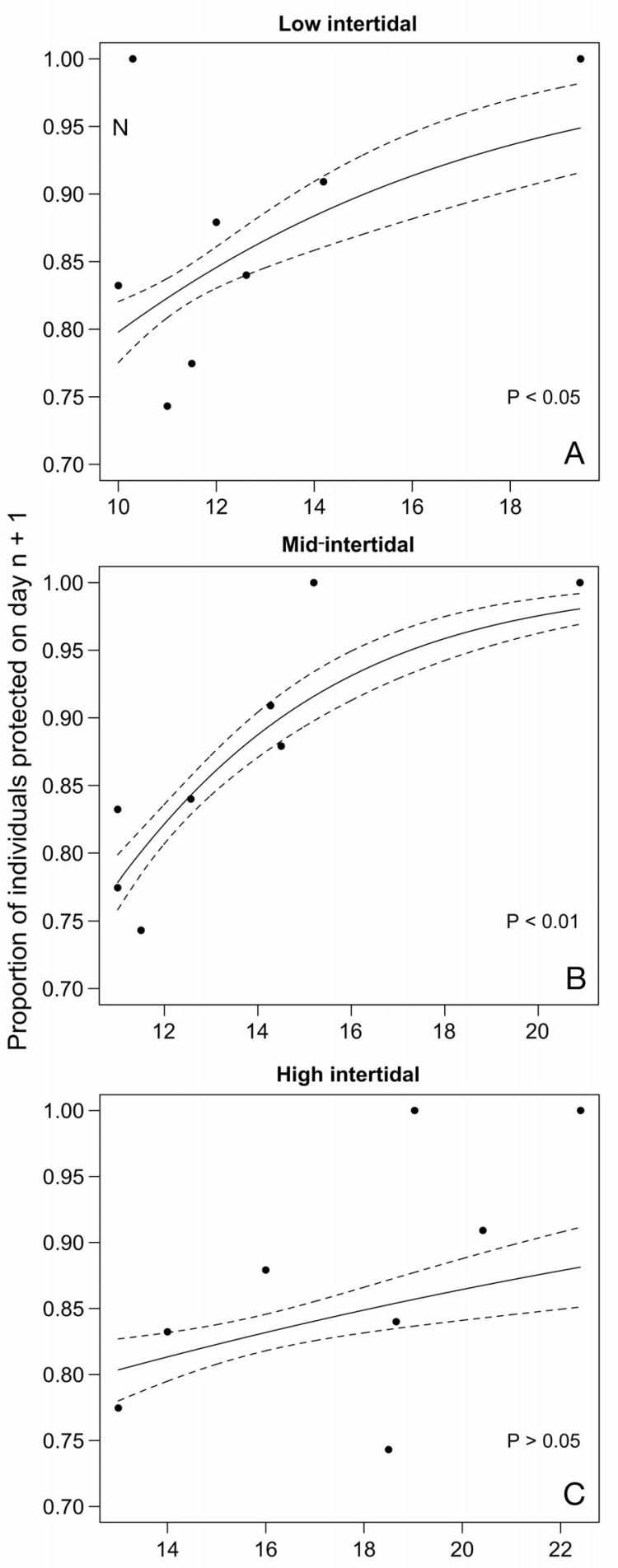

Maximum robo-sea star temperature on day $n\left({ }^{\circ} \mathrm{C}\right)$

Fig. 2. Proportion of Pisaster ochraceus individuals found in heat-protected thermal refugia on Day $n+1$ vs. potential maximum body temperatures on Day $\mathrm{n}$ experienced at 3 intertidal heights: (A) low, (B) mid, and (C) high $(0,1$, and $1.5 \mathrm{~m}$ above MLLW, respectively). Data were collected at the Bodega Marine Reserve, CA, in 2011 and 2012. Temperatures were recorded using robo-sea stars. The lines represent logistic regression fits $\pm 1 \mathrm{SE}$ 


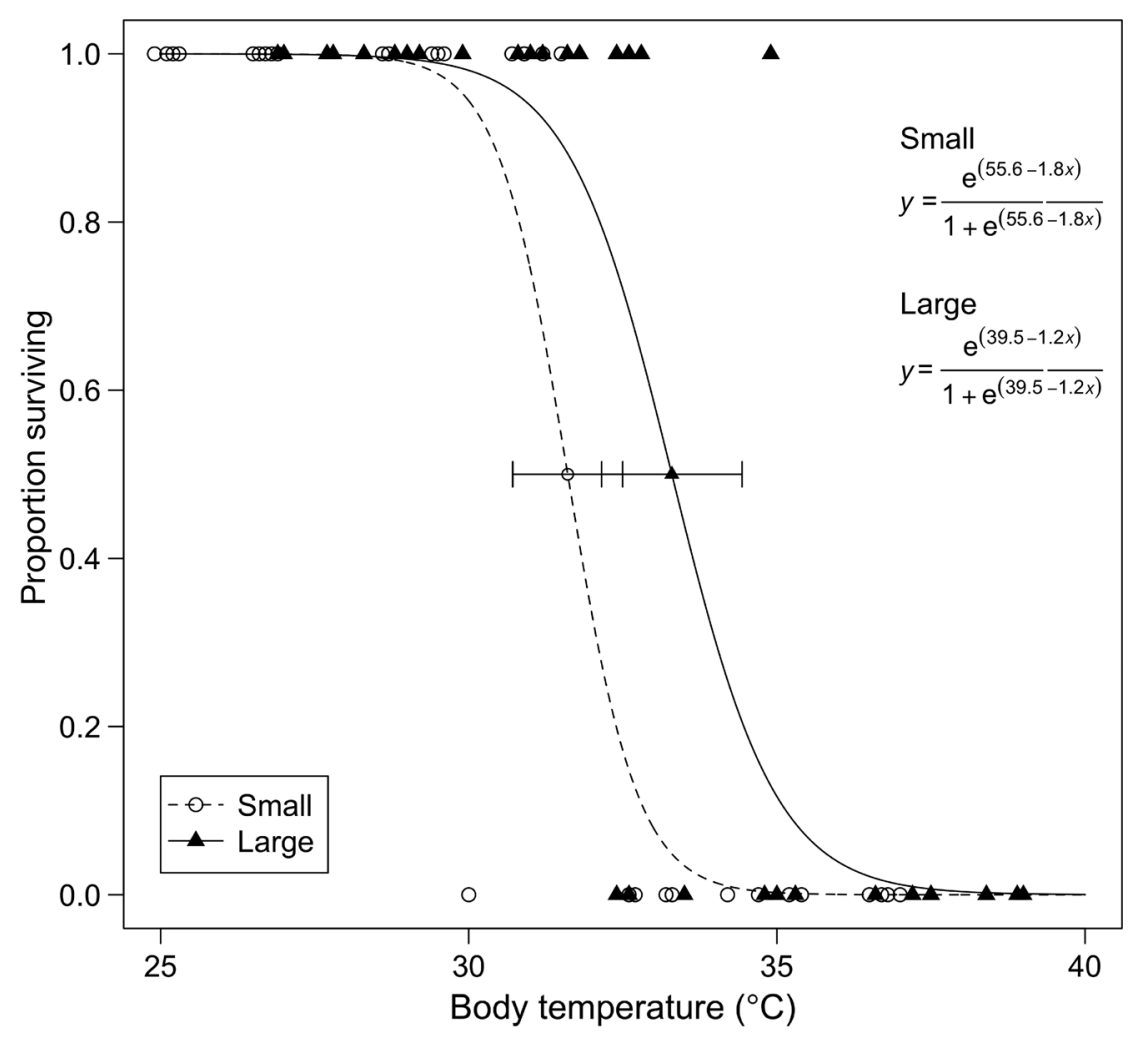

Fig. 3. Proportion of Pisaster ochraceus individuals surviving a series of aerial body temperature treatments. Lethal temperatures were experimentally determined for 2 size classes, small (25 to $75 \mathrm{~g}, \mathrm{~N}=34$ ) and large (250-400 g, $\mathrm{N}=33)$, by fitting independent logistic regressions. The body temperatures $( \pm$ $\mathrm{SE}$ ) at which $50 \%$ of individuals die (i.e. $\mathrm{LT}_{50}$ ) are indicated on each logistic regression line. The logistic model equations for each size class, and their estimated parameter values, are also provided

explained by their specific location: the former received more solar radiation than the rest, and the latter was in a rather shallow pool which may have heated more than deep ones.

Thermal conditions differed between sites. High intertidal temperatures at Bodega were higher than at Strawberry Hill $\left(22.5 \pm 4.4^{\circ} \mathrm{C}\right.$, vs. 19.9 $\pm 3.6^{\circ} \mathrm{C}$, mean $\pm 1 \mathrm{SD}_{i}$ paired $t$-test, $t_{47}$ $=-3.44, p<0.01$ ). In crevices, mean daily maxima were much more similar $\left(13.4 \pm 1.6^{\circ} \mathrm{C}\right.$ at Bodega, $12.8 \pm$ $1.8^{\circ} \mathrm{C}$ at Strawberry Hill; paired $t$-test, $\left.t_{46}=-2.15, \mathrm{p}<0.05\right)$. The variance in daily temperature maxima did not vary with site ( $F$-test, $\mathrm{p}>0.05$ comparing high intertidal and crevice loggers).

\section{Physiological consequences of microhabitat selection}

Consistent with our expectation, the percentage of time spent at temperatures above the optimal thermal performance breadth $\left(>23.8^{\circ} \mathrm{C}\right)$ was small, $<5 \%$ in every case (Table 2 ). In mid- and high intertidal microhabitats, Pisaster at Bodega experienced slightly more time above this thresh-

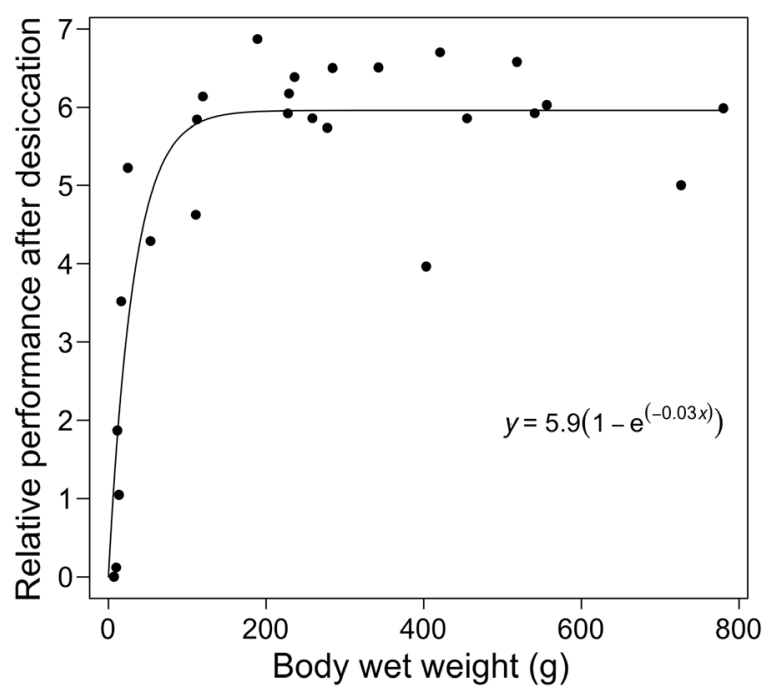

Fig. 4. Pisaster ochraceus relative performance after $3 \mathrm{~d}$ experiencing simulated $6 \mathrm{~h}$ low tide periods with 3-4 $\mathrm{m} \mathrm{s}^{-1}$ wind speeds, in relation to body size ( 7.1 to $780.1 \mathrm{~g}, \mathrm{~N}=26$ ). 2-parameter asymptotic exponential model parameters are indicated old than at Strawberry Hill. However, contrary to expectation, the proportion of time spent within the thermal performance breadth $\left(17.2-23.8^{\circ} \mathrm{C}\right)$ was also low $(<5 \%)$ for every microhabitat, except the high intertidal at Strawberry Hill and Bodega, where it reached values of 7.5 and $6.4 \%$, respectively. For all microhabitats at both sites, Pisaster spent most of the time $(>90 \%)$ at body temperatures markedly lower than the optimal thermal performance breadth $\left(<17.2^{\circ} \mathrm{C}_{i}\right.$ Table 2, Fig. 5).

\section{Survival probability}

The cumulative probability of survival was markedly high at both sites, and for both large and small individuals (Fig. 6). Only the high intertidal zone at Bodega showed potentially risky conditions for large and small Pisaster, for which final cumulative survival was 0.87 and 0.59 , respectively (Fig. $6 \mathrm{~B}, \mathrm{D}$ ). 

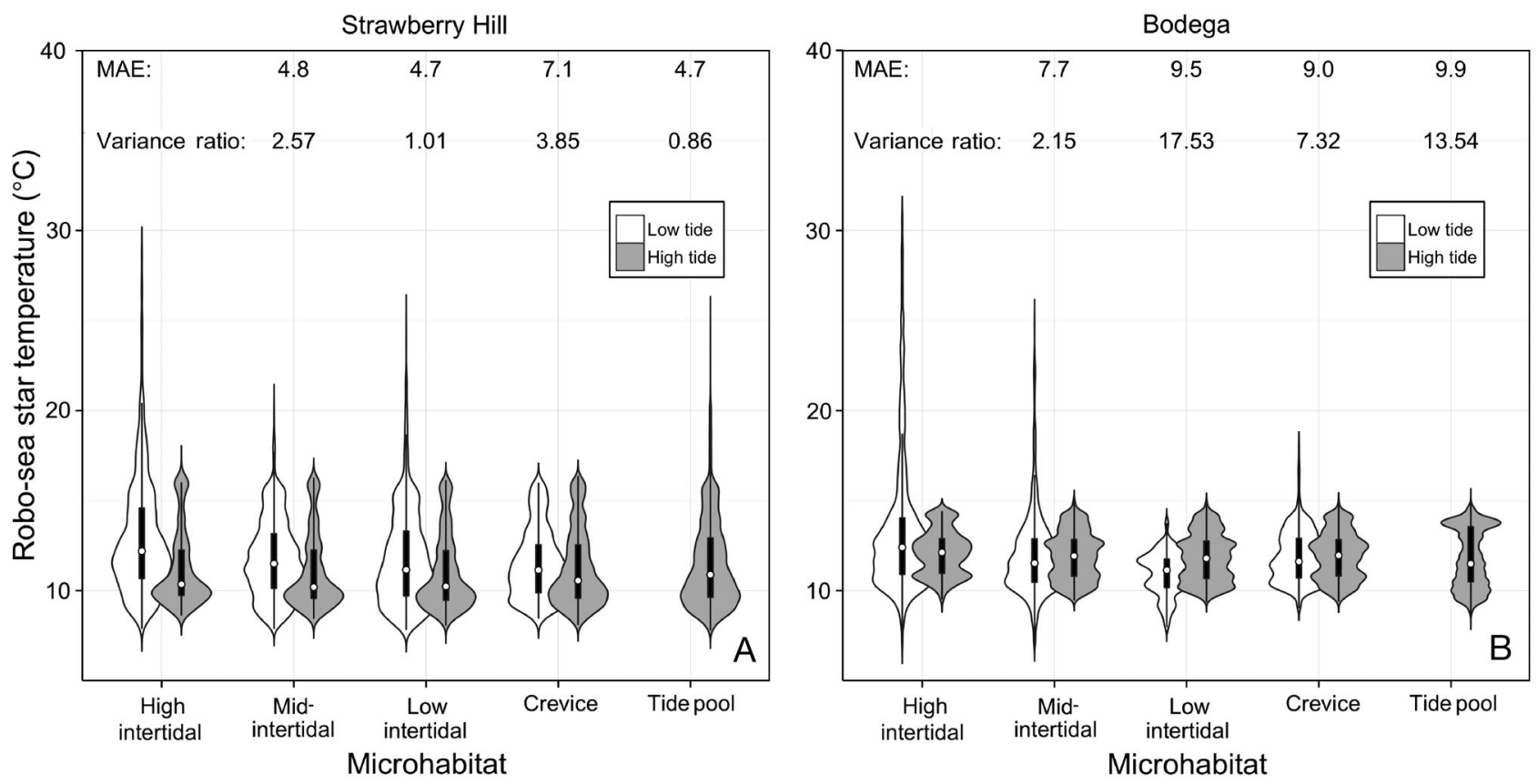

Fig. 5. Pisaster ochraceus body temperatures recorded by robo-sea stars (15 min sampling frequency) deployed in 5 different microhabitats at (A) Strawberry Hill, OR, and (B) the Bodega Marine Reserve, CA, between 6 June and 22 August 2012. High, mid-, and low intertidal are sun-exposed, while crevice and tide pool are heat-protected. Data are provided as violin plots with box plots embedded; the line represents the range, the box defines the 25th and 75th\% quartile, and the dot represents the median. For each microhabitat, data were split between measurements taken while loggers were exposed to air (white) or submerged under water (gray). Comparisons between daily temperature maxima of each microhabitat and the high intertidal (reference) were made based on mean absolute errors (MAEs), and variance ratios are given. The MAE values were calculated for each microhabitat without discriminating between tide periods

\section{DISCUSSION}

This study was designed to test among alternative mechanisms responsible for microhabitat selection and shore-level size gradients. Previous studies have attributed observed patterns to predation risk (Vermeij 1972), preference for prey of a given size based on their energetic profitability (Bertness 1977), differential sensitivity to temperature and desiccation between size classes (Frank 1965), and differences in the risk of desiccation due to the effect of size on surface area to volume ratios (McQuaid 1982). Our results are most consistent with those of Raffaelli \& Hughes (1978), who suggested that the availability of refuges can determine shore-level size gradients.

\section{Shore-level size gradients}

Consistent with previous work (Feder 1956, Fly et al. 2012), Pisaster exhibited shore-level size gradients, with larger individuals found lower on the shore. We found this in $2 / 3$ of surveys of protected animals, but not for animals in sun-exposed microhabitats (Table 1). This pattern varied both temporally and
Table 2. Potential physiological consequences for Pisaster ochraceus of occupying different microhabitats. Data represent percentage of time experiencing potential body temperatures (as measured by robo-sea stars) that fall below $\left(<17.2^{\circ} \mathrm{C}\right)$, within $\left(17.2-23.8^{\circ} \mathrm{C}\right)$, and above $\left(>23.8^{\circ} \mathrm{C}\right)$ Pisaster thermal performance breath $(69 \%$ of maximum performance). Thermal performance breath was determined from a performance curve empirically derived by Monaco et al. (2014)

\begin{tabular}{|lrcc|}
\hline Site/Microhabitat & \% Below & \% Within & \% Above \\
\hline Strawberry Hill, OR & & & \\
High intertidal & 91.33 & 7.51 & 1.19 \\
Mid-intertidal & 98.88 & 1.12 & 0.00 \\
Low intertidal & 97.77 & 2.20 & 0.03 \\
Crevice & 100.00 & 0.00 & 0.00 \\
Tide pool & 97.76 & 1.99 & 0.25 \\
Bodega Marine Reserve, CA & & \\
High intertidal & 90.99 & 6.45 & 2.56 \\
Mid-intertidal & 98.82 & 1.05 & 0.13 \\
Low intertidal & 99.97 & 0.03 & 0.00 \\
Crevice & 99.92 & 0.08 & 0.00 \\
Tide pool & 100.00 & 0.00 & 0.00 \\
\hline
\end{tabular}

geographically (Figs. S1 \& S2 in the Supplement, Table 1). Given that this species can travel several meters during high tide periods (Robles et al. 1995), it 

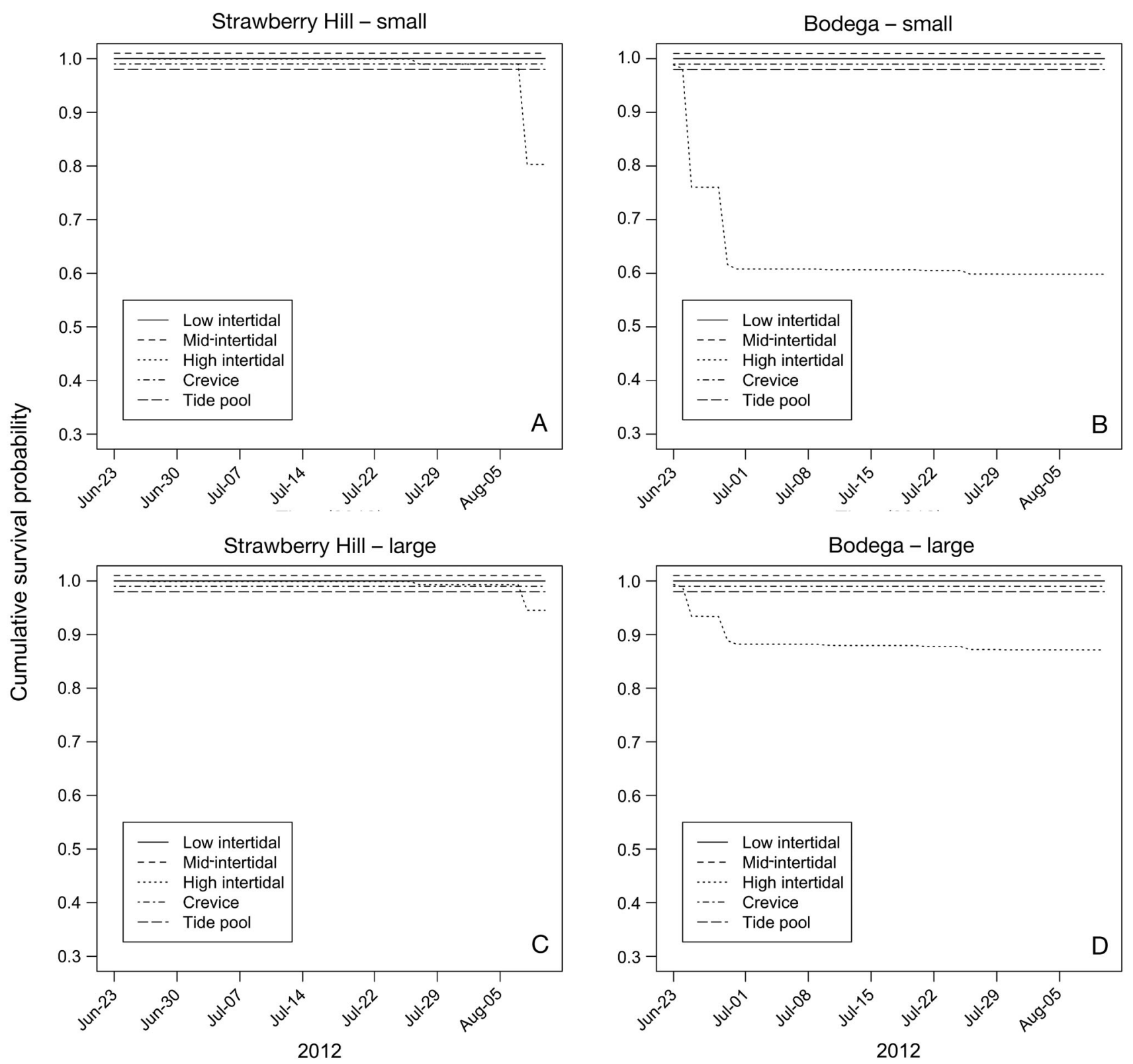

Fig. 6. Cumulative survival curves for hypothetical small (25-75 g) and large (250-500 g) Pisaster ochraceus individuals occupying various microhabitats (sun-exposed high, mid-, and low intertidal, and heat-protected in crevices or tide pools) available at the Bodega Marine Reserve, CA, and Strawberry Hill, OR. Survival was calculated based on our empirical estimates of mortality in relation to body temperature (see 'Materials and methods'). We slightly displaced curves that overlapped one another

is not surprising that its distribution patterns changed over time. The bulk of the week-to-week variation (Table 1) was driven by vertical displacements of larger animals (Figs. S1 \& S2 in the Supplement). We speculate that 2 main factors determine this phenomenon. First, while submerged during high tide, larger Pisaster are more active and travel faster than small individuals (C. Monaco unpubl.). Second, Pisaster avoids physical stressors by seeking protection before low tide (Garza \& Robles 2010, Robles et al. 1995); however, we suggest that because larger animals can- not benefit from small crevices, they are often forced to move towards the milder subtidal zone. Therefore, only sheltered animals exhibit shore-level size gradients. Exposed animals are presumably not seeking refuge, and do not exhibit this pattern.

\section{Microhabitat selection}

As expected, most Pisaster were found in microhabitats protected from the elements (Table 1), which 
reinforces the idea that this species avoids physical stressors (Robles et al. 1995, Burnaford \& Vasquez 2008, Pincebourde et al. 2008, Garza \& Robles 2010, Fly et al. 2012) and possibly predators like gulls (Morris et al. 1980) during low tide. A larger fraction of the Pisaster was in sun-exposed microhabitats at Strawberry Hill than Bodega (Table 1). At Strawberry Hill, sea star densities are significantly higher than at Bodega, so predation pressure on Mytilus californianus is higher and prey densities are lower. Consequently, Pisaster at Strawberry Hill consume fewer $M$. californianus, forage longer, and eat less profitable prey. We suggest that this foraging behavior might explain the longer time spent by Strawberry Hill Pisaster in sun-exposed microhabitats during low tides.

\section{Role of microclimate in habitat selection}

To estimate the influence of microclimate on habitat selection, we examined the slopes of the regressions between intertidal height and body size (shore-level size gradients), and refuge use (sunexposed/heat-protected). We found no association between shore-level size gradients and air temperature, solar radiation, seawater temperature, wind speed, or wave height on the previous day (Table S1 in the Supplement). However, the proportion of individuals found in thermal refugia was positively correlated with air temperature and solar radiation on the previous day (Fig. 1).

We also evaluated the effect of body temperatures measured in situ using biomimetic loggers (Szathmary et al. 2009). Although body temperature recorded by robo-sea stars were not correlated with shore-level size gradients, they were positively correlated with the fraction of individuals found in heatprotected microhabitats (Fig. 2A,B), consistent with active selection of sheltered microhabitats (Robles et al. 1995, Garza \& Robles 2010). Selection of heatsheltered microclimates may also explain Sanford's (1999) observation that the strength of interaction between Pisaster and its prey was not related to air temperature conditions in Oregon.

\section{Body temperatures across microhabitats and potential consequences}

To determine physiological consequences of microhabitat selection, we used the body temperature time series from the robo-sea stars, and a ther- mal performance curve for Pisaster (Monaco et al. 2014). Pisaster selects cool microhabitats (Table 1) where respiratory performance is low (Table 2) rather than warmer sites where respiratory performance is higher, and where its predation rates on mussels are higher (Sanford 1999). Behavioral selection for temperatures below the performance optimum has been widely documented in ectotherms (e.g. Martin \& Huey 2008, Tepler et al. 2011). The concept of 'sub-optimal is optimal' (Martin \& Huey 2008) maintains that ectotherms select temperatures lower than those that yield the highest fitness based on (1) the negatively skewed shape of a thermal performance curve, including that of Pisaster (Monaco et al. 2014), and (2) the fact that ectotherms are imperfect behavioral thermoregulators. A negatively (left) skewed curve means that, if field body temperatures are close to or at optimal, an increase in body temperature (to the right) generates a greater depression in performance than a decrease in temperature by the same amount. Accordingly, given the high thermal heterogeneity in the rocky intertidal, selecting for cool and thermally homogeneous microhabitats (e.g. crevices) may grant Pisaster a higher cumulative fitness than what can be expected from warmer (seemingly more profitable) microhabitats (e.g. sun-exposed high intertidal) through the avoidance of rare but damaging extreme temperatures. Thus, in heat-protected microhabitats (Table 1) where conditions are cooler and homogeneous (Fig. 5), Pisaster avoids upper critical temperatures (Martin \& Huey 2008).

It has been commonly documented that intertidal organisms live very close to their thermal tolerance limits (Stillman 2002, Wethey 2002, Jones et al. 2009, Denny et al. 2011; but see Mislan et al. 2014). However, given Pisaster's preference for cool microhabitats (Table 1), cumulative probability of survival with respect to body temperatures was high in all microhabitats (Fig. 6).

\section{Size-dependent tolerance to thermal and desiccation stress}

Contrary to expectation (Landenberger 1969, Pörtner 2002, Peck et al. 2009), the upper critical temperature $\left(\mathrm{LT}_{50}\right)$ (Fig. 5) and resistance to desiccation from wind stress was higher for the large size class of Pisaster (Fig. 6). The latter finding matches biophysical predictions based on surface area to volume ratios (McQuaid 1982, Allen et al. 2012). Neither of these results would explain the presence of larger animals 
lower on the shore. Although we observed a relationship between body size and intertidal height of $\mathrm{Pi}$ saster, it was only evident for individuals found in refugia.

Consistent with Vermeij (1972), as a low intertidal organism, Pisaster exhibited a negative relationship between body size and shore level; however, negative biotic interactions do not appear to drive the pattern. Bertness' (1977) hypothesis that prey size can drive the predator shore level was not tested here but may be applicable to Pisaster, given this predator's preference for consuming particular mussel sizes (Paine 1974, McClintock \& Robnett 1986, Gooding \& Harley 2015). Despite differential sensitivity to temperature and desiccation between sizes, this relationship was opposite to the distribution patterns observed in the field, not supporting the hypotheses by Frank (1965) and McQuaid (1982). As argued by Raffaelli \& Hughes (1978), we suspect that the shorelevel size gradient shown by Pisaster might be better explained by the availability of proper refugia. Because most individuals are found in protected microhabitats (Table 1), among which potential body temperatures are quite similar (Fig. 5), conditions experienced between size classes are ultimately very similar. Thus, as long as suitable microhabitats are available, the refuge-seeking behavior of Pisaster (Robles et al. 1995, Garza \& Robles 2010) is not dependent on size.

We have explored the possibility that life-threatening exposure to critical temperatures may drive Pisaster intertidal distribution, and suggested a bethedging strategy against rare but potentially fatal events. We did not evaluate the subtle effects of temperatures on energy balance components (investment in maintenance, growth, and reproduction), which, as argued by Robles (2013), directly translate to Darwinian fitness in Pisaster. Energy maximization may be an important driver of sea stars' behavior and therefore deserves further research.

Although we only worked at 2 coastal locations, we believe that the range of environmental conditions studied is representative of conditions found over much of the geographic range of the species. As documented by investigators on both the US Pacific coast (Helmuth \& Hofmann 2001, Helmuth et al. 2006, Denny et al. 2011) and the European coast (Seabra et al. 2015), the difference in thermal conditions between sun-exposed and shaded microhabitats is often greater than the thermal difference between sites separated by as much as $1000 \mathrm{~km}$.

\section{CONCLUSIONS}

Our results indicate that shore-level size gradients in the keystone predator $P$. ochraceus result primarily from a preference for cool microhabitats and the low availability of sheltered sites for large individuals at high shore levels. Contrary to expectation, the small difference in $\mathrm{LT}_{50}$ between size classes, and the fact that wind stress has a greater effect on small individuals (Fig. 4), suggests that size-dependent sensitivity to high temperature and desiccation does not explain the distribution patterns. Avoidance of lethal temperatures during normal daily low tide exposures appears to be unlikely, since body temperatures were rarely high enough to cause mortality (Fig. 6). However, these results match a growing body of literature that suggests that some animals may sacrifice increased performance in order to ensure a wider safety margin during rare but potentially lethal conditions (e.g. Martin \& Huey 2008).

Acknowledgements. We are grateful to Jay Pinckney, Tarik Gouhier, Eric Sanford, Carlos Robles, and 2 anonymous reviewers for constructive comments on the manuscript. Eric Sanford and Jackie Sones provided valuable insights about the study system and logistic support. We thank the Bodega Marine Lab (UC-Davis) and their Aquatic Resource Group for physical space and assistance while running experiments. Francis Choi, Allison Matzelle, Jerod Sapp, and Mackenzie Zippay helped to collect field data. Funding was provided by the US National Science Foundation to B.H. (OCE-0926581) and D.S.W. (OCE-1129401), the National Aeronautics and Space Administration (NNX11AP77G) to B.H. and D.S.W., and a Graduate Assistance in Areas of National Need fellowship (GAANN P200A090301) to C.J.M. This is publication number 327 of the Northeastern University Marine Science Center and 83 of the University of South Carolina Ecological Forecasting Group.

\section{LITERATURE CITED}

Allen BJ, Rodgers B, Tuan Y, Levinton JS (2012) Size-dependent temperature and desiccation constraints on performance capacity: implications for sexual selection in a fiddler crab. J Exp Mar Biol Ecol 438:93-99

> Bertness MD (1977) Behavioral and ecological aspects of shore-level size gradients in Thais lamellosa and Thais emarginata. Ecology 58:86-97

Broitman BR, Szathmary PL, Mislan KAS, Blanchette CA, Helmuth B (2009) Predator-prey interactions under climate change: the importance of habitat vs body temperature. Oikos 118:219-224

Burnaford JL, Vasquez M (2008) Solar radiation plays a role in habitat selection by the sea star Pisaster ochraceus. Mar Ecol Prog Ser 368:177-187

> Denny MW, Daniel TL, Koehl MAR (1985) Mechanical limits to size in wave-swept organisms. Ecol Monogr 55:69-102

> Denny MW, Dowd WW, Bilir L, Mach KJ (2011) Spreading 
the risk: small-scale body temperature variation among intertidal organisms and its implications for species persistence. J Exp Mar Biol Ecol 400:175-190

Feder HM (1956) Natural history studies on the starfish Pisaster ochraceus (Brandt, 1835) in Monterey Bay area. $\mathrm{PhD}$ dissertation, Stanford University, Stanford, CA

Fly EK, Monaco CJ, Pincebourde S, Tullis A (2012) The influence of intertidal location and temperature on the metabolic cost of emersion in Pisaster ochraceus. J Exp Mar Biol Ecol 422-423:20-28

Frank PW (1965) The biodemography of an intertidal snail population. Ecology 46:831-844

> Garza C, Robles C (2010) Effects of brackish water incursions and diel phasing of tides on vertical excursions of the keystone predator Pisaster ochraceus. Mar Biol 157: 673-682

> Gedan KB, Bernhardt J, Bertness MD, Leslie HM (2011) Substrate size mediates thermal stress in the rocky intertidal. Ecology 92:576-582

> Gooding RA, Harley CDG (2015) Quantifying the effects of predator and prey body size on sea star feeding behaviors. Biol Bull (Woods Hole) 228:192-200

> Helmuth B (2002) How do we measure the environment? Linking intertidal thermal physiology and ecology through biophysics. Integr Comp Biol 42:837-845

> Helmuth BST, Hofmann GE (2001) Microhabitats, thermal heterogeneity, and patterns of physiological stress in the rocky intertidal zone. Biol Bull (Woods Hole) 201: 374-384

> Helmuth B, Broitman BR, Blanchette CA, Gilman S and others (2006) Mosaic patterns of thermal stress in the rocky intertidal zone: implications for climate change. Ecol Monogr 76:461-479

Hewson I, Button JB, Gudenkauf BM, Miner B and others (2014) Densovirus associated with sea-star wasting disease and mass mortality. Proc Natl Acad Sci USA 111: 17278-17283

Hobday A (1995) Body-size variation exhibited by an intertidal limpet: influence of wave exposure, tidal height and migratory behavior. J Exp Mar Biol Ecol 189:29-45

> Jackson AC (2010) Effects of topography on the environment. J Mar Biol Assoc UK 90:169-192

> Jones SJ, Mieszkowska N, Wethey DS (2009) Linking thermal tolerances and biogeography: Mytilus edulis (L.) at its southern limit on the east coast of the United States. Biol Bull (Woods Hole) 217:73-85

Landenberger DE (1969) Effects of exposure to air on Pacific starfish and its relationship to distribution. Physiol Zool 42:220-230

> Lawrence JM, Cowell BC (1996) The righting response as an indication of stress in Stichaster striatus (Echinodermata, Asteroidea). Mar Freshw Behav Physiol 27:239-248

> Marshall D, Baharuddin N, McQuaid C (2013) Behaviour moderates climate warming vulnerability in high-rockyshore snails: interactions of habitat use, energy consumption and environmental temperature. Mar Biol 160: 2525-2530

> Martin TL, Huey RB (2008) Why 'suboptimal' is optimal: Jensen's inequality and ectotherm thermal preferences. Am Nat 171:E102-E118

> McClintock JB, Robnett TJ (1986) Size selective predation by the asteroid Pisaster ochraceus on the bivalve Mytilus californianus: a cost-benefit analysis. Mar Ecol (Berl) 7: 321-332

McQuaid CD (1982) The influence of desiccation and pre- dation on vertical size gradients in populations of the gastropod Oxystele variegata (Anton) on an exposed rocky shore. Oecologia 53:123-127

Menge BA, Berlow EL, Blanchette CA, Navarrete SA, Yamada SB (1994) The keystone species concept: variation in interaction strength in a rocky intertidal habitat. Ecol Monogr 64:249-286

Mislan KAS, Helmuth B, Wethey DS (2014) Geographical variation in climatic sensitivity of intertidal mussel zonation. Glob Ecol Biogeogr 23:744-756

Monaco CJ, Wethey DS, Helmuth B (2014) A dynamic energy budget (DEB) model for the keystone predator Pisaster ochraceus. PLoS ONE 9:e104658

Morris RH, Abbott DP, Haderlie EC (1980) Intertidal invertebrates of California. Stanford University Press, Stanford, CA

Paine RT (1966) Food web complexity and species diversity. Am Nat 100:65-75

> Paine RT (1969) The Pisaster-Tegula interaction: prey patches, predator food preference, and intertidal community structure. Ecology 50:950-961

> Paine RT (1974) Intertidal community structure: experimental studies on the relationship between a dominant competitor and its principal predator. Oecologia 15:93-120

> Peck LS, Clark MS, Morley SA, Massey A, Rossetti H (2009) Animal temperature limits and ecological relevance: effects of size, activity and rates of change. Funct Ecol 23: $248-256$

Peck LS, Souster T, Clark MS (2013) Juveniles are more resistant to warming than adults in 4 species of Antarctic marine invertebrates. PLoS ONE 8:e66033

Pincebourde S, Sanford E, Helmuth B (2008) Body temperature during low tide alters the feeding performance of a top intertidal predator. Limnol Oceanogr 53:1562-1573

> Pörtner HO (2002) Climate variations and the physiological basis of temperature dependent biogeography: systemic to molecular hierarchy of thermal tolerance in animals. Comp Biochem Physiol A Mol Integr Physiol 132: 739-761

> Pörtner HO (2006) Climate-dependent evolution of Antarctic ectotherms: an integrative analysis. Deep-Sea Res II 53:1071-1104

> Power ME, Tilman D, Estes JA, Menge BA and others (1996) Challenges in the quest for keystones. BioScience 46 : 609-620

Quinn GP, Keough MJ (2002) Experimental design and data analysis for biologists. Cambridge University Press, Cambridge

R Core Team (2013) R: a language and environment for statistical computing. R Foundation for Statistical Computing, Vienna

Raffaelli DG, Hughes RN (1978) The effects of crevice size and availability on populations of Littorina rudis and Littorina neritoides. J Anim Ecol 47:71-83

Robles CD (2013) Pisaster ochraceus. In: Lawrence JM (ed) Starfish: the biology and ecology of the Asteroidea. John Hopkins University Press, Baltimore, MD

Robles C, Sherwood-Stephens R, Alvarado M (1995) Responses of a key intertidal predator to varying recruitment of its prey. Ecology 76:565-579

Sanford E (1999) Regulation of keystone predation by small changes in ocean temperature. Science 283:2095-2097

> Sanford E (2002) Water temperature, predation, and the neglected role of physiological rate effects in rocky intertidal communities. Integr Comp Biol 42:881-891 
Seabra R, Wethey DS, Santos AM, Lima FP (2015) Understanding complex biogeographic responses to climate change. Sci Rep 5:12930

Sharpe PJH, DeMichele DW (1977) Reaction kinetics of poikilotherm development. J Theor Biol 64:649-670

Stevenson RD (1985) Body size and limits to the daily range of body temperature in terrestrial ectotherms. Am Nat 125:102-117

Stillman JH (2002) Causes and consequences of thermal tolerance limits in rocky intertidal porcelain crabs, genus Petrolisthes. Integr Comp Biol 42:790-796

Szathmary PL, Helmuth B, Wethey DS (2009) Climate

Editorial responsibility: James McClintock,

Birmingham, Alabama, USA change in the rocky intertidal zone: predicting and measuring the body temperature of a keystone predator. Mar Ecol Prog Ser 374:43-56

Tepler S, Mach K, Denny M (2011) Preference versus performance: body temperature of the intertidal snail Chlorostoma funebralis. Biol Bull (Woods Hole) 220: 107-117

Vermeij GJ (1972) Intraspecific shore-level size gradients in intertidal molluscs. Ecology 53:693-700

Wethey DS (2002) Biogeography, competition, and microclimate: the barnacle Chthamalus fragilis in New England. Integr Comp Biol 42:872-880

Submitted: February 9, 2015; Accepted: September 4, 2015 Proofs received from author(s): October 30, 2015 